\title{
ANALISIS KODE PADA MOP-MOP (KAJIAN SEMIOTIK)
}

\author{
oleh \\ Putri Wahyuni, Maulidawati ${ }^{*}$ \& Syahriandi \\ "Dosen Program Studi Pendidikan Bahasa Indonesia, FT Universitas Malikussaleh \\ Email: putriwahyuni@gmail.com
}

\begin{abstract}
ABSTRAK
Penelitian ini bertujuan untuk mendeskripsikan (1) kode-kode yang terdapat dalam naskah Mop-mop di antaranya kode teka-teki, kode konotatif, kode simbolik, dan kode tindakan, (2) mendeskripsikan makna yang terdapat dalam naskah Mop-mop. Data penelitian ini berupa kode-kode semiotik Roland Barthes yang terdapat dalam naskah Mop-mop. Teknik pengumpulan data penelitian ini adalah teknik baca dan teknik catat. Hasil penelitian yang diperoleh adalah (1) kode-kode yang terdapat dalam naskah Mop-mo, yaitu kode teka-teki (2), kode konotatif(11), kode simbolik (11), dan kode tindakan sebanyak (6), (2) makna yang terdapat dalam naskah Mop-mop di antaranya, makna dialog Meureuhui, makna salam pembuka, dan makna pantun nipah. Kode teka-teki yang terdapat dalam naskah Mop-mop sudah menunjukkan pertanyaan dan teka-teki. Kode konotatif yang terdapat dalam naskah Mop-mop merupakan kilasan-kilasan makna atau kata-kata yang mempunyai makna tersirat. Kode simbolik yang terdapat dalam naskah Mop-mop merupakan perlambangan bahasa yang sering disebut dalam kehidupan sehari-hari orang Aceh. Selanjutnya, kode tindakan yang terdapat dalam naskah Mop-mop memerlihatkan tindakan-tindakan yang disebutkan pada teks. Dalam penelitian ini, peneliti tidak menemukan adanya kode budaya dalam naskah Mop-mop.
\end{abstract}

Kata Kunci: Semiotik, Kode, Mop-Mop

\section{PENDAHULUAN}

Sastra merupakan suatu ungkapan jiwa yang dituangkan pengarang dalam sebuah karya. Selain itu, sastra juga berfungsi sebagai media hiburan. Fungsi sastra dalam kehidupan sosial adalah untuk mengomunikasikan ide, pikiran, serta perasaan manusia dalam bentuk lisan dan tulisan.

Karya sastra merupakan suatu karya yang dipandang sebagai refleksi dari kehidupan nyata. Keberadaan karya sastra sangat berdampingan dalam kehidupan masyarakat. Bahkan, banyak kejadian dalam kehidupan masyarakat yang dijadikan sebagai objek oleh pengarang dalam menciptakan karya sastra.

Dalam kehidupan sosial, dikenal ada dua bentuk karya sastra, yaitu sastra lisan dan sastra tulisan. Antara sastra lisan dan tulis memiliki hubungan timbal balik. Sastra tulisan adalah sastra yang menggunakan media tulisan dalam pengungkapan ide, pikiran, serta gagasan, sedangkan sastra lisan adalah karya sastra yang berada dalam lingkungan masyarakat atau disebut juga sebuah 
karya yang diwariskan secara turuntemurun dalam bentuk lisan.

Salah satu contoh sastra tulis dalam bentuk naskah yang dipentaskan dengan pertunjukan adalah Mop-mop atau yang dikenal dengan biola Aceh. Mop-mop adalah sastra lisan Aceh yang ditampilkan dalam bentuk pementasan teater, Mop-mop merupakan sebuah pementasan yang diperankan oleh tiga orang, yaitu ayah dara barô, dara barô, dan lintô barô. Mop-mop dikenal sebagai salah satu sastra lisan yang mempunyai nilai sastra yang tinggi. Hal itu ditandai penggunaan bahasanya terdapat makna yang mendalam serta jarang dipahami maksudnya oleh masyarakat.

Bahasa yang digunakan dalam naskah dapat berupa sindiran, teka-teki, dan sebagainya. Beberapa contoh yang dapat peneliti tampilkan adalah sebagai berikut. Salamu'alaikum nyang po rumoh, neubri ijin siat lôn keuneuk meucalitra (Assalamu'alaikum yang punya rumah, izinkan saya sebentar untuk bercerita). Pada contoh tersebut kode tindakan pada kata meucalitra (bercerita). Contoh tersebut menunjukkan bahwa seseorang menyampaikan maksud kepada tuan rumah untuk bercerita atau dalam adat Aceh disebut sebagai acara seumapa pada acara perkawinan. Contoh lainnya juga dapat dilihat pada kutipan "Takoh lipah tapula lipah pucôk jih reubah u dalam paya". Di dalam kutipan tersebut terdapat kode teka-teki. Pada contoh tersebut, seseorang bermain balas pantun dengan lawannya, kemudian ia ingin lawannya memecahkan solusi atau mencari jawaban dari teka-teki tersebut.

Di dalam sastra lisan seperti Mopmop terdapat makna simbolis sehingga diperlukan teori untuk mengkajinya. Salah satu teori yang digunakan untuk mengkaji karya sastra adalah semiotik. Teori semiotik sangat berpengaruh dalam karya sastra karena dalam sastra bahasa merupakan lambang atau tanda yang sangat sarat dengan penanda.
Sahid (2016:2) mengatakan bahwa semiotik adalah ilmu tentang tanda dan sistem tanda. Pendekatan semiotik merupakan salah satu pendekatan yang mempunyai sistem sendiri, yaitu berupa sistem tanda. Tanda dalam sastra khususnya sastra yang berbentuk tulisan dibuat dalam bentuk teks. Pesan dalam Mop-mop dapat kita ketahui dengan cara menganalisis Mop-mop tersebut. Makna dalam Mop-mop dapat dianalisis berdasarkan tanda yang terdapat dalam di dalamnya.

Ada beberapa penelitian yang relevan dengan penelitian yang akan peneliti lakukan. Penelitian yang relevan pernah dilakukan oleh Agustina (2017) dalam jurnal penelitiannya yang berjudul Analisis Semiotik dalam Kumpulan Cerpen Air mata Ibuku dalam Semangkuk Sup Ayam. Penelitian ini bertujuan untuk mengetahui pesan yang ingin disampaikan pengarang kepada pembaca. Dalam hasil penelitiannya, Agustina mengatakan bahwa dalam cerpen Air mata Ibuku dalam Semangkuk Sup Ayam terdapat beberapa kode, yaitu kode tekateki, simbolis, aksian, dan budaya. Berbeda dengan penelitian yang akan dilakukan ini, peneliti ingin meneliti tentang kode-kode yang terdapat dalam naskah Mop-mop serta ingin mengetahui pesan yang terdapat dalam kode-kode tersebut.

Selanjutnya, Hafiar dkk. (2017) dalam jurnal penelitiannya yang berjudul Analisis Semiotika pada Cover Novel Trilogi Karya Vira Safitri. Tujuan dari penelitiannya adalah untuk mengetahui lebih lanjut mengenai simbol, makna simbol, serta bagaimana simbol dalam ilustrasi cover novel karya Vira Safitri mampu membangun kesan yang terbentuk di benak pembaca novelnya. Dalam penelitian Hafiar dkk. disebutkan bahwa bahwa simbol yang dianggap memiliki makna yang disengaja adalah objek gambar bunga, gambar alat/properti, dan warna. Ilustrasi pada 
cover novel Trilogi karya Vira Safitri telah mampu menggambarkan profesi sang tokoh, lokasi tempat berlangsungnya kisah, serta telah mampu untuk mendukung kesan elegan, romantis, dan happy ending yang menjadi ciri khas novel kisah cinta. Berbeda dengan penelitian yang akan dilakukan ini, peneliti hanya mengkaji kode-kode yang terdapat dalam naskah Mop-mop serta makna yang terdapat dalam naskah Mopmop tersebut.

Penelitian sebelumnya juga pernah diteliti oleh Albar (2018) dalam jurnal penelitiannya yang berjudul Analisis Semiotik Charles Sander Pierce Tentang Taktik Kehidupan Manusia: Dua Karya Kontemporer Putu Sutawijaya. Tujuan dari penelitian ini adalah untuk mengkaji representasi taktik kehidupan manusia dalam dua karya seni rupa kontemporer Putu Sutawijaya. Dalam hasil penelitiannya Albar mengatakan bahwa Putu Sutawijaya senantiasa memiliki konsep yang konsisten dan memiliki otoritas penuh dalam proses kreatifnya melalui pengalamannya yang mampu memberikan wacana dan sublimasi dalam seni rupa kontemporer di Indonesia. Berbeda dengan penelitian yang akan dilakukan ini, peneliti hanya mengkaji kode-kode yang terdapat dalam naskah Мор-тор.

Berdasarkan pemaparan di atas, peneliti tertarik untuk menganalisis kodekode yang terdapat dalam Mop-mop. Kode-kode yang terdapat dalam Mopmop tersebut peneliti analisis berdasarkan makna. Dalam penelitian ini, peneliti menggunakan pendekatan semiotik Barthes. Menurut Barthes (dalam Agustina, 2017:55), ada lima sistem kode dalam kajian semiotik, yaitu (1) kode teka-teki, (2) kode konotatif, (3) kode simbolis, (4) kode aksian, dan (5) kode budaya. Oleh karena itu, judul penelitian ini adalah "Analisis Kode pada Mop-mop (Kajian Semiotik).”

\section{KAJIAN TEORITIS \\ Pengertian Mop-mop}

Mop-mop atau yang lebih dikenal dengan sebutan biola Aceh merupakan salah satu sastra lisan Aceh yang telah lama hidup di Aceh, yaitu semenjak zaman Kolonial Belanda. Pada tahun 50an, di Aceh Utara, Aceh Besar, dan Pidie adalah daerah yang pertama memulai kesenian ini. Penamaan terhadap kesenian ini karena penggunaan instrumen biola sebagai alat musik utama.

Ada beberapa ahli yang memberikan definisi tentang Mop-mop. Menurut Budhiman (dalam Aiman, 2017:114), biola Aceh merupakan kesenian rakyat yang berbentuk teater dari Aceh. Pemberian nama biola Aceh karena biola digunakan sebagai instrumen musik utama dalam pertunjukan. Setiap daerah punya penamaan tersendiri terhadap biola Aceh. Masyarakat Aceh Utara menyebutnya dengan sebutan Mopmop, sedangkan di Aceh Besar dan Pidie menyebutnya Geundrang Kleng.

Selain itu, Aiman (2017:115) mengatakan bahwa kesenian Mop-mop berasal dan tumbuh di Kabupaten Pidie sejak tahun 50-an. Pada tahun 60-an kesenian ini menyebar luas ke daerah lain terutama di Kabupaten Aceh Utara. Masyarakat Aceh Utara sangat menggemari kesenian Mop-mop ini. Pada umumnya, pertunjukan kesenian ini digemari oleh masyarakat pedesaan.

Selanjutnya, Aiman juga mengatakan bahwa kesenian Mop-mop diciptakan oleh Karman bin Po dari Aceh Utara, kemudian dikembangkan oleh sanggar Meurak Jeumpa Aceh di Kecamatan Muara Batu Kabupaten Aceh Utara pada tahun 1994 yang beranggotakan Syekh Ishak Bungkah dari Kecamatan Dewantara sebagai pemain biola dan pemeran tokoh abi/ayah, Syekh Ghani dari Kecamatan Sawang sebagai pemeran Dara Barô/pengantin wanita, 
dan Ampon Usman dari Kecamatan Muara Batu sebagai pemeran Lintoe Barô/pengantin pria. Di Aceh Utara, kesenian ini sangat terkenal. Salah satu bentuk rasa cinta seniman terhadap kesenian ini adalah setelah pertunjukan selesai, alat musik biola selalu ditutupi dengan kain putih.

Dari pendapat ahli di atas, dapat disimpulkan bahwa Mop-mop merupakan seni pertunjukan yang ditampilkan dalam bentuk teater. Dalam pertunjukan Mopmop pertunjukan tersebut dimainkan oleh tiga pemeran. Tiga orang pemeran dalam pertunjukan Mop-mop, yaitu syekh yang memainkan alat musik dan berperan sebagai vokalis, dua orang pelawak berperan sebagai lintoe barô (pengantin pria) dan dara barô (pengantin wanita).

\section{Pengertian Semiotika}

Semiotik berasal dari bahasa Yunani, yaitu semeion yang berarti tanda. Eco (dalam Sobur, 2002:95) mengatakan bahwa semiotik didefinisikan sebagai sesuatu yang atas dasar konvensi sosial yang terbangun sebelumnya, tanda dapat dianggap mewakili sesuatu yang lain. Berdasarkan pendapat tersebut, tanda dianggap sebagai sesuatu yang tersirat yang dapat mewakili sesuatu yang lain.

Para ahli memberikan definisi mengenai semiotika. Salah satunya Teeuw (dalam Sobur, 2002:96) mengatakan bahwa semiotik adalah tanda sebagai tindak dalam komunikasi. Selanjutnya, ia menyempurnakan batasan semiotik itu sebagai model sastra yang mempertanggungjawabkan semua faktor dan aspek tentang pemahaman susastra sebagai alat komunikasi yang khas. Semiotik merupakan tanda yang akan menjawab segala pemahaman yang mewakili sesuatu yang lain.

Pendapat lainnya juga dikemukakan oleh Cristomy dan Untung Yuwono (dalam Muthia, 2016:40) semiotika merupakan ilmu yang mempelajari tentang tanda (sign), fungsi tanda, dan produksi makna. Tanda adalah sesuatu yang bagi seseorang berarti sesuatu yang lain. Semiotik mengkaji tanda, penggunaan tanda dan segala sesuatu yang bertalian dengan tanda. Dengan kata lain, perangkat pengertian semiotik dapat diterapkan pada semua bidang kehidupan asalkan prasyaratnya dipenuhi, yaitu ada arti yang diberikan, ada pemaknaan dan ada interprestasi

Selain itu, Barthes (dalam Agustina, 2017:46) mengemukakan pendapat bahwa semiotika adalah ilmu atau metode analisis untuk mengkaji tanda. Tanda-tanda tersebut merupakan alat yang dipakai untuk mencari jalan di dunia ini, di tengah-tengah manusia dan bersama manusia. Semiotika pada dasarnya digunakan untuk mempelajari bagaimana memaknai hal-hal. Memaknai dalam hal ini tidak bisa dicampuradukkan dengan komunikasi. Memaknai dalam hal ini dikatakan bahwa objek-objek tidak hanya membawa informasi, tetapi juga mengkonstitusi sistem terstruktur dari tanda.

Lebih lanjut, Barthes (dalam Muthia, 2016:41) juga mengatakan bahwa bahasa merupakan sebuah sistem tanda yang mencerminkan asumsi-asumsi dari masyarakat tertentu dalam waktu tertentu. Barthes menggunakan teori signifiant-signifie yang dikembangkan menjadi teori tentang metabahasa dan konotasi. Namun, Barthes mengatakan antara antara $\mathrm{E}$ dan $\mathrm{C}$ harus ada relasi (R) tertentu sehingga membentuk tanda (sign, $S n$ ). Konsep relasi ini membuat teori tentang tanda lebih mungkin berkembang karena relasi ditetapkan oleh pemakai tanda.

Wiryaatmadja (dalam Yuliantini dan Adita, 2017:66) menyatakan bahwa "Semiotika adalah ilmu yang mengkaji kehidupan tanda dalam maknanya yang luas di dalam masyarakat, baik yang lugas, yang menggunakan bahasa, maupun non-bahasa." Bahasa yang dianggap sebagai sistem tanda sering kali 
mengandung sesuatu yang tersirat. Sesuatu yang terlihat terkadang tidak sesuai dengan keadaan yang sebenarnya. Tanda-tanda tersebut diungkapkan melalui penanda. Oleh karena itu, penulis menggunakan semiotik untuk memberikan makna bagi tanda-tanda dalam teks yang dikaji.

Sejalan dengan pendapat di atas, Ratna (dalam Yuliantini dan Adita, 2017:67) juga mengemukakan pendapat bahwa semiotika merupakan studi sistematis mengenai produksi dan interpretasi tanda serta manfaatnya terhadap kehidupan manusia. Semiotik bertujuan untuk mengetahui maknamakna yang terdapat dalam sebuah tanda atau menafsirkan makna dalam tanda tersebut sehingga dapat diketahui bagaimana isi pesan tersebut. Semiotik dapat berupa tanda-tanda ataupun simbolsimbol.

Berdasarkan penjelasan para ahli di atas, dapat disimpulkan bahwa semiotik adalah suatu ilmu yang digunakan untuk mengkaji tentang tanda. Tanda-tanda tersebut diungkap melalui penanda. Tanda-tanda yang terdapat di dalamnya ditafsirkan untuk mengetahui makna di dalamnya.

\section{Semiotika Roland Barthes}

Agustina (2017:25) menyatakan bahwa bahwa semiotika Barthes tersusun atas tingkatan-tingkatan sistem bahasa. Umumnya, Barthes membuatnya dalam dua tingkatan bahasa. Bahasa tingkat pertama adalah bahasa sebagai objek dan bahasa tingkat kedua yang disebut dengan meta bahasa. Bahasa ini merupakan suatu sistem tanda yang menurut penanda dan petanda.

Selanjutnya, Kaelan (dalam Agustina, 2017:26) mengatakan bahwa kode semiotik Barthes terdiri atas lima kode, yaitu kode hermeneutik (kode tekateki), kode semik (makna konotatif), kode simbolik, kode proaretik (logika tindakan), dan kode budaya atau kultural yang membangkitkan suatu pengetahuan. Adapun penjelasan kelima kode tersebut adalah sebagai berikut.

a. Kode hermeneutik

Nasution

mengemukakan bahwa kode hermeneutik merupakan kode berhubungan dengan teks-teks yang timbul ketika teks mulai dibaca. Siapakah tokoh ini? Bagaimanakah peristiwa itu berlanjut? Jadi, didaftarkan beragam istilah, tekateki yang dapat dibedakan, diduga, diformulasikan, dipertahankan, dan akhirnya disingkap. Apa sebenarnya istilah atau teka-teki tersebut. Kode ini disebut juga "Suara Kebenaran" (The Voice of Truth). Oleh karena itu, dapat dikatakan bahwa kode teka-teki merupakan kode dengan unsur struktur yang utama dalam narasi. Narasi tersebut adalah adanya suatu peristiwa yang muncul serta menjadi teka-teki dalam penyelesaiannya. Kode teka-teki merupakan jawaban atas permasalahan yang muncul.

b. Kode konotatif

Astika (2014:16) mengatakan bahwa kode konotatif merupakan penanda yang mengacu pada gambarangambaran mengenai kondisi psikologi tokoh, suasana atmosferik suatu tempat atau objek tertentu. Kode konotatif adalah kode yang berada dalam kawasan penanda, yaitu penanda khusus yang memiliki konotasi atau penanda materialnya sendiri tanpa rantai penandaan pada tingkat ideologis karena sudah menawarkan konotasi. Kode semantik merupakan penanda bagi dunia konotasi yang ke dalamnya mengalir kesan atau nilai rasa tertentu.

Kode semik atau konotasi berhubungan dengan tema-tema yang terdapat dalam penyusunan teks. Kode ini mengandung arti tambahan, perasaan tertentu, dan nilai rasa selain makna dasar. Jika di dalam teks dapat ditemukan konotasi, berarti dalam teks tersebut dapat ditemukan sebuah tema. Oleh 
karena itu, dapat dikatakan bahwa kode semik merupakan kode yang berhubungan dengan tema dalam suatu teks. Selain itu, kode semik juga berfungsi sebagai isyarat atau kemungkinan makna dalam suatu tanda. Jika dalam suatu teks ditemukan konotasi, dapat dipastikan suatu teks tersebut terdapat sebuah makna.

c. Kode simbolik

Djajasudarma (dalam Adri, 2009:251) mengatakan bahwa tanda dalam bentuk huruf-huruf disebut sebagai lambang atau simbol yang tertulis dan apa yang kita dengar dari seseorang yang berfungsi sebagai alat komunikasi yang disebut lambang atau simbol. Kode simbolik sebenarnya berkaitan dengan tema sehingga mempunyai hubungan yang erat dengan kode konotasi, yaitu tema dalam keseluruhan teks cerita. Simbol merupakan aspek pengodean fiksi yang khas bersifat struktural. Hal tersebut berdasarkan gagasan bahwa makna berasal dari beberapa oposisi biner atau pembedaan baik dalam taraf bunyi menjadi fonem dalam proses produksi wicara, maupun pada taraf oposisi psikoseksual yang melalui proses. Oleh karena itu, dapat dikatakan bahwa kode simbolik merupakan kode dalam bentuk huruf yang dikatakan sebagai sebuah simbol atau lambang. Selain itu, kode simbolik merupakan kode yang menunjukkan perbedaan, seperti perbedaan siang dan malam. Dalam kode simbolik, pola yang ditandai tersebut merupakan pola yang diikuti orang.

d. Kode praoretik

Kode praoretik atau kode tindakan sering dianggap sebagai pelengkap utama dalam teks yang sering dibaca orang, artinya semua teks tersebut bersifat naratif. Astika (2014:16) mengatakan bahwa kode kultural atau kode referensial adalah kode yang mengatur dan membentuk suara-suara kolektif dan anonim dari pertandaan yang berasal dari pengalaman manusia dan tradisi yang beraneka ragam. Kode ini dalam pengertian yang luas adalah penandapenanda yang merujuk pada seperangkat referensi atau pengetahuan umum yang mendukung teks. Unit-unit kode ini dibentuk oleh keberanekaragaman pengetahuan dan kebijaksanaan yang bersifat kolektif. Dalam mengungkapkan kode ini, analisis cukup mengindikasikan adanya tipe-tipe pengetahuan yang menjadi rujukan tersebut, misalnya filsafat, psikologi, sosiologi, dan sebagainya.

e. Kode budaya

Rusmana (dalam Agustina, 2017:29) mengatakan bahwa kode kultural adalah kode yang berasal dari suara-suara kolektif yang anonim dan otoritatif. Kode ini mengenai pengetahuan, kebijaksanaan, atau moralitas yang diterima bersama, misalnya kesucian, kesakralan, atau baik dan buruk. Kode ini berhubungan dengan budaya berdasarkan latar cerita dalam teks. Kode kultural merupakan kode yang diacu ke benda-benda yang sudah dikodifikasi oleh budaya.

Rendi (2017:19) mengatakan bahwa Kode kultural adalah sebuah referensi untuk sebuah ilmu pengetahuan atau tubuh dari pengetahuan. Kode ini mempunyai hubungan dengan budaya yang terdapat dalam teks. Latar sosial budaya yang terdapat dalam sebuah cerita rekaan memungkinkan adanya suatu kesinambungan maupun penyimpangan dari budaya sebelumnya. Oleh karena itu, dapat dkatakan kode budaya atau kultural merupakan kode yang mempunyai kaitan antara budaya dengan cerita dalam teks. Kode kultural adalah kode yang mengacu pada tempat atau benda-benda yang berhubungan dengan budaya. Selain itu, kode budaya dianggap sebagai referensi sebuah ilmu atau lembaga pengetahuan.

\section{METODE PENELITIAN}

Pendekatan penelitian ini adalah pendekatan kualitatif. Sugiyono (2017:3) 
mengatakan bahwa pendekatan kualitatif adalah pendekatan berkenaan dengan data yang bukan angka, pendekatan ini bersifat naratif. Selanjutnya, penelitian kualitatif adalah penelitian yang melakukan analisis dan interpretasi teks dengan tujuan menemukan makna dari suatu fenomena. Pendekatan kualitatif adalah pendekatan yang digunakan untuk mendeskripsikan atau mengurai data dalam bentuk tulisan yang tidak berkenaan dengan data berupa angka Jenis penelitian ini adalah hermeneutik. Penelitian hermeneutik adalah penelitian yang dianggap sebagai kaidah-kaidah untuk menginterpretasikan teks atau kumpulan potensi tanda-tanda yang dipandang sebagai teks.

Sumber data merupakan sumber yang sangat diperlukan dalam melakukan penelitian. Sumber data penelitian ini adalah Mop-mop. Data penelitian ini berupa kode-kode semiotik Roland Barthes yang terdapat Mop-mop.

Dalam penelitian ini, peneliti menggunakan dua teknik pengumpulan data, yaitu teknik baca dan teknik catat. Teknik ini dipilih untuk memeroleh data secara langsung dari objek penelitian.
Teknik baca adalah teknik yang digunakan dengan cara membaca data untuk mengetahui keseluruhan isi pada objek penelitian berdasarkan rumusan masalah. Selanjutnya, peneliti juga menggunakan teknik catat dalam penelitian ini. Teknik catat adalah cara yang dilakukan untuk mencatat data-data yang ada hubungan dengan penelitian. Teknik analisis data dilakukan dengan tahap-tahap yang dijabarkan melalui kegiatan-kegiatan identifikasi data, reduksi data, penyajian data, dan penarikan kesimpulan.

\section{HASIL PENELITIAN}

Setelah dilakukan penelitian terhadap naskah Mop-mop, ditemukan data mengenai kode-kode semiotik dan makna dalam naskah Mop-mop. Kodekode yang ditemukan dalam Mop-mop adalah kode teka-teki, kode konotatif, kode simbolik, dan kode tindakan. Sebelum penulis membahas data penelitian tentang kode semiotik Roland Barthes yang terdapat dalam naskah Mop-mop, penulis menyajikan data dalam bentuk tabel sebagai berikut.

Tabel 1

Kode semiotik Roland Barthes dalam Naskah Mop-mop

\begin{tabular}{|c|c|c|}
\hline No. & $\begin{array}{l}\text { Kode Semiotik } \\
\text { Roland Barthes }\end{array}$ & Data \\
\hline 1. & Kode Hermeneutik & $\begin{array}{l}\text { 1) Takoh lipah tapula lipah } \\
\text { Pucok jih reubah u dalam paya } \\
\text { Meunyoe hiem nyoe jeut neupeuglah } \\
\text { Jadeeh meunikah geutayoe dua } \\
\text { 2) Lintô Barô : Digata nak ta deungö haba Cudajéh } \\
\text { Dara Barô : Keupu neujak peudalèh Cuda jéh, } \\
\text { lông eu keudroe lông malam nyan droeneuh } \\
\text { meubalah-balah pantôn. }\end{array}$ \\
\hline 2. & Kode konotatif & $\begin{array}{l}\text { 3) Ta preh droeneuh ba cit han neutem ba, cit kana } \\
\text { alasan neuh. Meunyoe han neu ngieng le neu puwoe } \\
\text { long bak ayah } \\
\text { 4) Ayah bik inoeng hantöm galak si agam, sedangkan } \\
\text { si inoeng cukôp galak ngön si agam } \\
\text { 5) Bila kah jak keunan maka ma'op nyan akan di pajôh }\end{array}$ \\
\hline
\end{tabular}




\begin{tabular}{|c|c|c|c|}
\hline & & $\begin{array}{l}\text { 6) } \\
\text { 7) } \\
\text { 8) } \\
\text { 9) } \\
\text { 10) } \\
\text { 11) } \\
\text { 13) }\end{array}$ & $\begin{array}{l}\text { tanyoe } \\
\text { Lö that ta sayang makajih lö that dalèh } \\
\text { Meunyoe ta gaséh salah pih beuna } \\
\text { Ureung meulaôt ngön ureung meugoe meunan keu } \\
\text { dua droe panca utama } \\
\text { Bek kajak keunan, nyan ma'op } \\
\text { Adak tajak u Peureulak Idi, ku keubah boh giri } i \\
\text { keudé Cunda } \\
\text { Jadi lông duek siat tamsé lông piyôh dang-dang trôh } \\
\text { reu'oh laen lôn nak ba } \\
\text { Lintô Barô : Digata nak ta deungö haba Cuda jéh } \\
\text { Dara Barô : Keupu neujak peudalèh Cuda jéh, lông } \\
\text { eu keudroe lông malam nyan droeneuh meubalah- } \\
\text { balah pantôn } \\
\text { Awai keubut dudoe pike }\end{array}$ \\
\hline 3. & Kode simbolik & $\begin{array}{l}14) \\
15) \\
16) \\
17) \\
18, \\
19) \\
20 \\
21) \\
22, \\
23, \\
24)\end{array}$ & $\begin{array}{l}\text { Meureuhui } \\
\text { Boh giri meujak-jak } \\
\text { Bue droep daruet } \\
\text { Hikayat lam aroen } \\
\text { Awai keubut dudoe pike } \\
\text { Panté labön } \\
\text { Lintô Barô } \\
\text { Dara Barô } \\
\text { Perlak batèe } \\
\text { Meunasah } \\
\text { Tarék pukat }\end{array}$ \\
\hline 4. & Kode tindakan & $\begin{array}{l}25 \\
26 \\
27 \\
28 \\
29 \\
30\end{array}$ & $\begin{array}{l}\text { Keupu neujak peu dalèh keu cuda jéh, lông eu } \\
\text { keudroe lông malam nyan droeneuh meubalah } \\
\text { pantôn } \\
\text { Lôn izin siat keuneuk meudiwana } \\
\text { Musang meujanggôt teungöh di pajôh manok } \\
\text { Takoh lipah tapula lipah } \\
\text { Tarék pukat } \\
\text { Ta ék u glée tajak kôh sigeudum }\end{array}$ \\
\hline
\end{tabular}

\section{PEMBAHASAN}

\section{1) Kode teka-teki}

Dalam naskah Mop-mop terdapat dua kode teka-teki. Kode teka-teki adalah kode yang berisi teka-teki yang merupakan jawaban dari pertanyaan pembaca. Adapun kode teka-teki yang terdapat dalam naskah Mop-mop, yaitu tentang perkawinan dan konflik dalam rumah tangga. Kode teka-teki dalam naskah Mop-mop dijabarkan sebagai berikut.

Takoh lipah tapula lipah

Pucôk jih reubah u dalam paya
Meunyoe hi'em nyoe jeut neupeuglah

Jadéeh meunikah geutanyoe dua

Terlihat pada kutipan di atas bahwa pantun tersebut merupakan tekateki. Adapun kode teka-teki di atas merupakan kode teka-teki tentang lamaran perkawinan. Pantun di atas berisi teka-teki yang membuat pembaca menerka-nerka jawabannya. Dibait terakhir pantun di atas, penutur mengatakan bahwa jika lawan tutur dapat membalas teka-tekinya, mereka akan menikah. 
Selain teka-teki tentang pantun di atas, dalam Mop-mop juga terdapat kode teka-teki tentang percintaan atau kehidupan rumah tangga. Dalam kehidupan rumah tangga banyak konflik atau kejadian yang terjadi. Salah satu konflik yang tak lazim terjadi dalam kehidupan rumah tangga kehadiran orang ketiga. Hal ini terdapat pada kutipan di bawah ini.

Lintô Barô : "Digata nak ta deungö haba Cuda jéh."

Dara Barô : "Кeupu neujak peudalèh Cuda jéh, lông eu keudroe lông malam nyan droeneuh meubalah-balah pantôn."'

Kutipan di atas merupakan kode teka-teki karena perempuan yang dibicarakan dalam dialog di atas tidak disebutkan siapa. Kode teka-teki di atas termasuk ke dalam kode tekai-teki percintaan. Adapun dalam dialog di atas Lintô Barô membantah tidak pernah melakukan itu dan mengatakan jangan mendengarkan perkataan perempuan tersebut. Namun, dalam cerita di atas tidak dijelaskan siapa perempuan tersebut.

Berdasarkan kutipan di atas, kode teka-teki yang terdapat dalam naskah Mop-mop sudah menunjukkan pertanyaan dari pembaca. Hal ini sesuai dengan teori yang dikatakan oleh Putri (2015:19) bahwa kode teka-teki merupakan kode yang menentukan misteri dan ketegangan (suspence) dengan membantu pembaca mengenali apa yang dianggap sebagai teka-teki dan menyusun rincian-rincian sebagais kontribusi yang memungkinkan adanya pemecahan. Kode hermeneutik atau kode teka-teki merupakan kode yang mengandung teka-teki atau belitan tanda tanya yang ditemukan dan dirasakan oleh pembaca. Teka-teki tersebut membangkitkan hasrat dan kemauan untuk mendapatkan jawaban dari sebuah pertanyaan inti yang terdapat dalam karya sastra. Teka-teki tersebut memunculkan pertanyaan-pertanyaan sehingga pembaca berusaha untuk menemukan jawaban. Pembaca dihadapkan dengan sesuatu yang tidak segera dapat dipahami dan di situlah dilakukan usaha interpretasi.

\section{2) Kode konotatif}

Berdasarkan hasil penelitian, terdapat sebelas kode konotatif dalam naskah Mop-mop. Kode konotatif merupakan kode yang mempunyai kilasan makna. Hal tersebut peneliti jabarkan sebagai berikut.

"Ta preh droeneuh ba cit han neutem ba, cit kana alasan neuh. Meunyoe han neu ngieng le neu puwoe lông bak ayah"

Kode konotatif di atas menunjukkan makna tersirat pada teks "meunyoe han neu ngieng le neupuwoe lông bak ayah." Teks tersebut mempunyai makna tersirat tentang keinginan sang istri yang ingin berpisah dengan suaminya. Kutipan di atas menjelaskan kemarahan Dara Barô yang tidak pernah dibawa ke mana-mana oleh suaminya. Dalam ucapannya tersebut, dia mengatakan jika suaminya sudah tidak menyukainya, ia meminta dipulangkan kepada ayahnya. Dari kutipan di atas, terlihat Dara Barô sudah tidak sanggup lagi untuk melanjutkan hubungan rumah tangga mereka.

Selain tentang percintaan kehidupan rumah tangga di atas, kejadian tentang percintaan dalam naskah Mopmop juga terjadi dikarenakan cinta terhalang restu. Kisah cinta yang terjalin tetapi harus berhenti di tengah jalan karena orang tua tidak merestui hubungan sang anak. Hal ini dapat dilihat pada kutipan berikut ini.

"Ayah bik inöng hantöm galak si agam, sedangkan si inông cukôp galak ngön si agam"

Kode konotatif pada kutipan di atas terlihat pada teks ayah bik inöng hantöm galak keu si agam. Pada teks 
tersebut mempunyai makna tersirat yaitu sang ayah yang tidak ingin anak perempuannya menikah dengan laki-laki pilihan anaknya. Pada kutipan di atas dijelaskan bahwa ayah dari perempuan tersebut tidak menyukai laki-laki yang disukai oleh anaknya. Namun, si perempuan sangat menyukai lelaki tersebut. dari kutipan di atas terlihat bahwa cinta antara si perempuan dan laki-laki tersebut tidak dapat restu dari ayah si perempuan.

Selain hal percintaan, dalam naskah Mop-mop juga terdapat cerita tentang hal mistis. Kepercayaan orang Aceh tentang ma'op merupakan suatu momok yang menakutkan. Hal dijelaskan pada kutipan berikut.

"Bek kajak keunan, nyan ma'op"

Pada kutipan di atas, dijelaskan tentang kepercayaan orang Aceh tentang $m a$ 'op yang dikenal untuk sebutan hantu. $M a$ 'op merupakan momok menakutkan yang sering berkeliaran di malam hari untuk mencari mangsa. Anggapan di atas sering dikatakan orang tua untuk menakuti anak-anak. Selain itu, kata ma'op juga sering digunakan untuk menakuti orang-orang agar tidak beranjak ke tempat yang telah dilarang. Hal ini dapat dilihat pada kutipan berikut.

"Bila kah jak keunan maka ma'op nyan akan di pajôh tanyoe"

Dijelaskan pada kutipan di atas tentang ma'op (atau sebutan Musang Meujanggot) merupakan hewan pemanggsa ayam di malam hari. Dikatakan ma'op ada pada tempat yang telah dilarang agar orang-orang tidak mendekat ke tempat yang telah dilarang tersebut. Hal tersebut dikarenakan tempat yang telah dilarang tersebut menyimpan hal yang bersifat mistis.

Dalam pertunjukan Mop-mop terdapat saleum atau salam pembuka untuk memulai pertunjukan. Saleum ini untuk menyapa penonton. Di akhir saleum, pemain pertunjukan juga mengucapkan kata-kata penutup. Hal ini dapat dilihat pada kutipan di bawah ini.

"Jadi lông duek siat tamsé lông piyôh dang-dang trôh reu'oh laen lôn nak ba"

Pada kutipan di atas, pemain pertunjukan dengan meminta izin kepada penonton untuk istirahat sebentar. Pemain pertunjukan meminta izin untuk beristirahat dikarenakan akan melakukan pertunjukkan di tempat yang lain. Dalam ucapannya tersebut, pemain pertunjukan akan menyebutkan tempat yang akan ia singgahi. Teks yang diucapkan oleh pemain pertunjukan akan berbeda-beda sesuai dengan tempat yang akan mereka kunjungi. Hal ini dijabarkan pada kutipan berikut.

"Adak tajak u Peureulak Idi, ku keubah boh giri i keudée Cunda”

Dijelaskan pada kutipan di atas bahwa walaupun mereka pergi ke Idi, mereka tidak akan melupakan pertunjukan yang telah mereka lakukan di Cunda. Pemain pertunjukkan mengakhiri salam pembuka dan akan melakukan pertunjukan di tempat lain. Kutipan di atas disebutkan tempat bahwa mereka akan melakukan pertunjukkan di Kota Peureulak, Aceh timur.

Berdasarkan kutipan di atas, kode konotatif yang terdapat dalam naskah Mop-mop sudah menunjukkan isyarat dan kilasan makna. Hal ini sesuai dengan teori Agustina (2017:27) menyatakan bahwa kode semik atau kode konotatif adalah kode konotasi yang memberikan isyarat, menunjuk kilasan makna, atau kemungkinan makna yang ditawarkan oleh penanda. Kode semik atau konotatif menawarkan banyak sisi, dalam proses pembacaan, pembaca menyusun tema suatu teks. Kode semik melihat bahwa konotasi kata atau frasa tertentu dalam teks dapat dikelompokkan dengan konotasi kata atau frasa yang mirip. 


\section{3) Kode Simbolik}

Ditemukan sebelas kode simbolik dalam naskah Mop-mop. Kode simbolik merupakan kode yang berupa lambang atau simbol. Adapun kode-kode simbolik yang terdapat dalam naskah Mop-mop, yaitu tentang simbol untuk perempuan dan perlambangan. Kode simbolik dalam naskah Mop-mop dijelaskan sebagai berikut.

\section{"Boh giri meujak-jak"}

Kutipan di atas merupakan kode simbolik yang sering di simbolkan sebagai perempuan yang tidak mempunyai malu. Boh giri disimbolkan sebagai perempuan yang hendak mandi menggunakan kain di kamar mandi yang berada di halaman depan rumah. Dari kutipan di atas, terlihat jelas bahwa pada zaman dulu di daerah pedesaan kamar mandi di setiap rumah berada di halaman depan. Tanpa disadari oleh masyarakat sekitar bahwa setiap anak gadis yang mandi mereka akan melewati arah depan dan dapat dilihat oleh orang-orang sekitar.

\section{"Meureuhui"}

Pada kutipan di atas, Meureuhui merupakan istilah yang dilambangkan kepada seorang wanita yang cemburu terhadap suaminya. Cerita Meureuhui tersebut merupakan gambaran tentang kehidupan rumah tangga dalam lingkungan sosial yang menunjukkan peristiwa budaya. Kehidupan rumah tangga di pedesaan sering terlihat jika ada masalah dalam rumah tangganya, hal tersebut akan tersebar di lingkungan masyarakat dan menjadi konsumsi publik.

\section{"Bue droep daruet"}

Pada kutipan di atas, dijelaskan bahwa bue merupakan seekor monyet yang mempunyai sifat yang gegabah dan ceroboh. Kata-kata di atas adalah sindiran untuk orang-orang yang licik dan serakah. Orang yang licik dan serakah akan harta atau jabatan akan melakukan berbagai cara untuk mendapatkan apa yang diinginkannya. Tanpa disadari, hal tersebut berdampak terhadap orang lain karena haknya telah diambil. Di zaman modern sekarang, sering kita lihat orangorang yang menindas orang yang tidak mampu untuk mendapatkan haknya.

\section{"Awai keubut dudoe piké"}

Kata-kata di atas merupakan sindiran untuk orang-orang yang suka bertindak bodoh tanpa memikirkan resiko yang akan terjadi ke depannya. Pada kutipan di atas menggambarkan tentang karakter orang yang suka bertindak sesuka hati, tetapi tidak memikirkan apa yang akan terjadi ke depannya. Teks di atas menunjukkan bahwa karakter orang di dalam teks tersebut merupakan orang yang tidak mau mendengar pendapat orang lain. Ia hanya akan melakukan pendapatnya sendiri tanpa mau berkompromi dengan orang lain dan tidak memikirkan resiko yang akan ia hadapi. Orang pada kutipan di atas juga disebut sebagai orang yang mempunyai karakter ceroboh.

\section{"Panté labön"}

Kutipan di atas merupakan sindiran untuk penyebutan nama tempat. Pada teks di atas menunjukkan lokasi yang disamarkan menjadi penanda. Dalam Mop-mop, tempat tertentu disamarkan atau dibalik penyebutannya hanya sebagai sindiran. Dalam penyebutannya, nama-nama tempat tersebut sebenarnya dibalik untuk menceritakan tempat atau peristiwa yang terjadi di lokasi pementasan yang bertempat pada tempat yang disebut dalam pementasan dengan bahasa terbalik.

"Perlak batèe"

Pada teks di atas menunjukkan teks di atas adalah penyebutan nama suatu daerah dengan bahasa terbalik. Ucapan teks di atas merupakan suatu bentuk kemarahan Lintô Barô karena tuduhan selingkuh yang dituduhkan istrinya. Ucapan tersebut diucapkan Lintô Barô 
untuk meredam emosinya. Selain itu, ucapan di atas juga menjadi suatu cara yang diucapkan oleh pemain pementasan untuk pemberitahuan tamu yang akan menampilkan pementasan.

Berdasarkan kutipan di atas, kode simbolik yang terdapat dalam naskah Mop-mop menujukkan tentang simbol dan perlambangan. Hal ini serupa dengan teori Astika (2014:16) mengatakan bahwa kode simbolik adalah kode yang mengatur kawasan antitesis dari tandatanda yang terdapat satu ungkapan atau tanda meleburkan dirinya ke dalam berbagai substitusi, keanekaragaman penanda dan referensi sehingga menggiring kita dari satu kemungkinan makna ke kemungkinan lainnya. Penanda-penanda dalam wilayah ini mempunyai banyak makna (multivalence) yang dapat saling bertukar posisi (reversibility). Kode simbolik merupakan kode yang mengatur aspek bawah sadar dari tanda dan dengan demikian merupakan kawasan dari psikoanalisis.

\section{4) Kode Tindakan}

Ditemukan enam kode tindakan dalam naskah Mop-mop. Kode tindakan merupakan tindakan atau kejadian yang terjadi dalam cerita. Adapun kode tindakan yang terdapat dalam naskah Mop-mop dijabarkan sebagai berikut.

"Keupu neujak peu dalèh keu cuda jéh, lông eu keudroe lông malam nyan droeneuh meubalah pantôn"

Pada kutipan di atas, kode tindakan yang terdapat pada kutipan di atas sudah menunjukkan adanya tindakan yang terjadi. Tindakan yang terjadi pada kutipan di atas adalah kegiatan yang dilakukan oleh Lintô Barô, yaitu berpantun dengan seorang perempuan. Lintô Barô diketahui sedang berbalas pantun dengan seorang perempuan. Dara Barô yang melihat aksi itu langsung emosi dan memarahi suaminya. Dari kegiatan berbalas-balas pantun yang dilakukan oleh Lintô Barô, terjadilah konflik dalam rumah tangga Lintô Barô dan Dara Barô. Lintô Barô adalah penyebab terjadinya konflik tersebut.

"Lôn izin siat keuneuk meudiwana"

Pada kutipan di atas menunjukkan adanya suatu kegiatan yang terjadi. Kode tindakan yang terjadi pada kutipan di atas adalah seseorang yang hendak ingin menceritakan suatu kejadian. Sebelum memulai bercerita, seseorang tersebut terlebih dahulu meminta izin kepada pendengar. Kegiatan yang terjadi pada kutipan di atas merupakan kegiatan yang dilakukan antara seorang pencerita dengan pendengar. Dari kegiatan tersebut adanya interaksi yang terjadi antara pembicara dengan pendengar.

\section{"Takoh lipah tapula lipah"}

Pada kutipan di atas kode tindakan pada teks di atas menunjukkan adanya kegiatan menanam yang dilakukan oleh seseorang. Pohon nipah merupakan sebuah pohon tempat penyu menyimpan telurnya. Kegiatan pada kutipan di atas merupakan kegiatan bercocok tanam. Kegiatan yang dilakukan adalah menanam pohon nipah dan memotong pohon nipah.

"Tarék pukat"

Pada kutipan di atas menunjukkan adanya suatu kegiatan yang terjadi. Sebagai daerah dengan pendapatan hasil laut yang melimpah, aceh mengapresiasi kegiatan Tarék pukat ini. Tarék pukat merupakan suatu kegiatan yang dilakukan oleh nelayan untuk mencari ikan. Kegiatan Tarék pukat adalah kegiatan yang dilakukan oleh orang pesisir pantai. Tarék pukat juga disebuat sebagai suatu kebudayaan yang terdapat di Aceh. Masyarakat bergotong-royong dalam melakukan kegiatan Tarék pukat. Dalam mengapresiasikan budaya Tarék pukat ini, diciptakan sebuah tarian yang dinamakan tarian Tarék pukat.

"Ta ék u glée tajak kôh sigeudum" 
Pada kutipan di atas menunjukkan adanya kode tindakan. Selain mencari pendapatan dengan hasil laut, masyarakat Aceh juga mencari pendapatan dengan mengandalkan hasil alam. Kegiatan ék $u$ glée atau berkebun merupakan kegiatan bercocok tanam yang dilakukan di daerah pegunungan. Kegiatan-kegiatan bercocok tanam masyarakat Aceh di antaranya, menanam cabai, bawang, pisang, dan lain sebagainya. Masyarakat yang menetap di daerah pegunungan mengandalkan mata pencahariannya dengan berladang. Hasil panen pendapatan mereka tersebut, mereka bawa ke kota untuk dijual kepada pedagang.

Berdasarkan kutipan di atas, kode tindakan yang terdapat dalam naskah Mop-mop sudah menunjukkan adanya tindakan atau kegiatan yang terjadi dalam teks. Hal ini sesuai dengan teori Budiman (dalam Yuliastuti, 2011:27) mengatakan bahwa kode tindakan merupakan tindakan (action) yang terjadi dalam cerita. Kode ini didasarkan atas konsep prioairesis, yaitu kemampuan untuk menentukan hasil atau akibat dari suatu tindakan secara rasional yang mengimplikasikan suatu logika perilaku manusia. Tindakan-tindakan tersebut membuahkan dampak-dampak, yang masing-masing dampak, memiliki hamahama genetik tersendiri, semacam judul dengan sekuens yang bersangkutan.

Lintô : "Na tajak nyoe?"

Dara barô : "Tapreh droeneuh ba cit han neutem ba, cit kana neupuwoe lông bak ayah." alasan neuh. Meunyoe han neunging le

\subsubsection{Makna Mop-mop}

\section{1) Makna Dialog Meureuhui}

Cerita Meureuhui dalam Mopmop merupakan suatu cerita yang sering terjadi dalam kehidupan sosial. Dalam kehidupan sosial, sering kita lihat konflik yang terjadi dalam rumah tangga. Pada cerita Meureuhui ini, konflik yang terjadi merupakan konflik yang disebabkan oleh Lintô Barô. Hal ini dijelaskan pada kutipan berikut.
Lintô
: "Digata tadeungo that haba Cuda jeh"
Dara barô : "Keupu neujak peudaleh keu cuda jeh, lông eu keudroe lông malam nyan droneuh meubalah-balah pantôn."

Pada kutipan di atas, terlihat kekesalan Dara Barô terhadap suaminya karena ia melihat sang suami berbalasbalas pantun dengan perempuan lain. Dara Barô merasa gelisah karena sang suami merespon dengan emosi ucapan yang dikatakannya tersebut. Dari kutipan di atas, dapat kita lihat bahwa Dara Barô cemburu atas tindakan yang dilakukan suaminya tersebut.Dari kutipan di atas, terlihat jelas bahwa Dara Barô tertekan dengan konflik yang sedang sdihadapinya. Ia merasa sang suaminya sudah tidak memedulikan dirinya lagi. Karena hal itulah, ia meminta dipulangkan kepada orang tuanya. Pada kutipan di atas merupakan awal mula konflik yang terjadi.
Lintô
: "Digata teungöh ujeun pih seu'uem teuh. Nyan keu piyasan lông sagai nyan."
Dara barô : "Nyan sigö-gö teuk neu eu keuh."

Pada kutipan di atas, terlihat Lintô Barô merespon jawaban dari pertanyaan Dara Barô dengan santai. Hal tersebut ia lakukan agar sang istri tidak melakukan hal-hal di luar batas kewajaran. Sang suami berusaha menjelaskan apa yang sebenarnya terjadi. Namun, Dara Barô yang sudah terlanjur marah tidak mau mendengar apa yang dikatakan Lintô Barô. Lintô Barô emosi karena merasa tertuduh oleh istrinya. Namun, ia tetap menjaga emosinya karena hal tersebut terjadinya disebabkan oleh dirinya sendiri. 
Konflik batin yang dirasakan itu membuatnya menaruh curiga terhadap suaminya dikarenakan pengaruh orang ketiga yang hadir dalam hubungan mereka. Dara Barô merasa suaminya berselingkuh dan menyembunyikan hubungan tersebut darinya. Dari sini terlihat bahwa Dara Barô tidak memercayai suaminya dan tidak mau mendengarkan penjelasan sang suami.

Sang suami yang merasa tertuduh berusaha meredam emosinya dan menjelaskan baik-baik apa yang sebenarnya terjadi. Namun, ia harus menerima kemarahan sang istri yang tidak mau mendengarkan apa pun yang ia katakan. Sikap suami pada cerita Meureuhui ini merupakan sikap yang mengalah atas kemarahan sang istri. Hal itu dikarenakan semua konflik yang bermula merupakan ulahnya sendiri.

Dari cerita Meureuhui ini dapat diambil pelajaran bahwa dalam hubungan suami istri harus ada kepercayaan. Cerita Meureuhui ini mengisahkan akan seorang istri yang takut kehilangan suami. Namun, karena kecemburuannya terhadap sang suami membuat hubungan mereka merenggang. Kesimpulan yang dapat diambil bahwa permasalahan yang terjadi dalam kehidupan rumah tangga harus diselesaikan dengan berdiskusi bersama-sama. Tanamkan rasa percaya pada pasangan. Sebagai seorang istri, jangan terlalu cemburu terhadap suami dengan menuduh dan memojokkan suami.

\section{2) Salam Pembuka}

Dalam kebudayaan orang Aceh, ada istilah kepercayaan makhluk tak kasat mata yang berada di suatu tempat. Salam pembuka dalam pementasan Mopmop merupakan pembuka untuk mengawali pertunjukan. Fungsi dari salam pembuka adalah untuk menghormati pemilik tempat lokasi pertunjukan dilakukan. Selain itu, tujuan pemain mengucapkan salam pembuka adalah untuk menjaga keselamatan pemain dari hal-hal yang tidak diinginkan. Hal ini dijelaskan pada kutipan berikut.

Salamu'alaikum yang Po teumpat

Pada kutipan di atas, pemain pertunjukan mengucapkan salam pembuka terlebih dahulu sebelum pementasan dimulai kepada penonton yang berada di lokasi pementasan. Salam pembuka di atas adalah untuk menyapa penonton serta sebagai bentuk rasa hormat karena telah memberikan izin untuk melakukan pementasan. Selain masyarakat yang hadir di lokasi pementasan, masyarakat mempercayai bahwa juga ada makhluk lain yang ikut menyaksikan pertunjukan tersebut.

meudiwana

Loeng izin siat lông keneuk

Pada kutipan di atas, teks di atas merupakan lanjutan dari salam pembuka. Kutipan di atas merupakan salam pembuka yang diucapkan oleh pemain untuk meminta izin melakukan pementasan. Dalam pementasan yang dilakukan tersebut, pemain menceritakan sebuah cerita yang dikemas dalam bentuk pertunjukkan yang menggambarkan kehidupan sebenarnya.

\section{Jadi lông duek siat tamsé \\ lông piyoh dang-dang \\ trôh reuoh hoe laen lông \\ nak ba}

Pada kutipan di atas, dijelaskan bahwa pemain pementasan meminta izin sebentar untuk beristirahat. Istirahat pada kutipan di atas adalah sebagai maksud untuk mengakhiri pertunjukan dan melakukan pertunjukan di tempat yang lain. Dengan mengatakan hal di atas, pemain pementasan mengakhiri pertunjukkannya pada tempat yang sedang berlangsung pementasan dan akan melanjutkan pementasan di tempat yang lain.

Adak tajak Peureulak Idi, kukubah boh giri i keudée Cunda 
Pada kutipan di atas dijelaskan bahwa pertunjukan pementasan akan berakhir. Pemain mengatakan walaupun mereka pergi ke Peureulak, mereka tetap menyimpan jeruk di Cunda. Maksud dari ucapan tersebut adalah mereka akan meninggalkan Aceh Utara tempat pertama mereka melakukan pementasan dan akan melanjutkan pementasan di Kota Peureulak, Aceh Timur.

Dari kutipan di atas, dapat disimpulkan bahwa salam pembuka dalam setiap pertunjukan diperlukan untuk mengawali sapaan kepada penonton. Salam pembuka merupakan bentuk rasa hormat yang dilakukan untuk menghormati penonton yang hadir pada pertunjukan. Selain itu, salam pembuka juga untuk menghormati makhluk lain yang juga dianggap hadir pada tempat pementasan.

\section{3) Pantun Nipah}

Syair dan pantun merupakan sastra lisan yang mempunyai nilai keindahan dalam pementasan. Syair dan pantun dalam pementasan Mop-mop diketahui bahwa keberadaannya yang terdapat di dalam pertunjukan mempunyai hubungan antara tanda dan penanda. Pantun nipah merupakan salah satu pantun yang berisikan teka-teki yang membuat orang bertanya-tanya akan jawabannya. Pantun nipah diucapkan seseorang kepada lawan tuturnya dengan harapan agar lawan tutur dapat menjawab teka-teki yang diucapkannya tersebut. Hal ini dijelaskan sebagai berikut.

Takoh lipah tapula lipah

Pucôkjih reubah u dalam paya

Pada kutipan di atas, dijelaskan bahwa penutur mengatakan teka-teki tentang pohon nipah. Teka-teki yang diucapkan, yaitu memotong nipah dan menanam nipah. Pohon nipah merupakan pohon tempat penyu bertelur.

Meunyoe hi'em nyoe jeut neupeuglah Jadéeh meunikah geutanyoe dua
Pada kutipan di atas, penutur memberikan teka-teki kepada lawan tutur. Dalam ucapannya, ia mengatakan bahwa jika lawan tutur dapat menjawab teka-teki dari penutur, mereka akan menikah. Penutur mengatakan teka-teki di atas dengan harapan lawan tutur dapat menjawabnya dan menerima lamaran penutur.

Dari kutipan di atas dapat disimpulkan bahwa pantun teka-teki merupakan pantun yang berisi teka-teki tentang lamaran. Penutur menyampaikan maksud lamarannya melalui pantun nipah. Tujuan dari pantun nipah yang diucapkan oleh penutur adalah agar lawan tutur dapat menjawab dan memberikan jawaban atas lamaran penutur.

\section{PENUTUP}

Berdasarkan penelitian di atas, simpulan dalam penelitian ini adalah sebagai berikut.

1) Kode-kode semiotik yang terdapat dalam naskah Mop-mop, yaitu:

a. kode teka-teki merupakan kode yang berisi teka-teki. Dalam naskah Mop-mop terdapat dua kode teka-teki;

b. kode konotatif merupakan kode yang bersifat isyarat atau disebut juga bahasa kiasan. Di dalam naskah Mop-mop ditemukan enam kode konotatif;

c. kode simbolik merupakan kode yang berupa simbol atau lambang. Dalam naskah Mop-mop terdapat enam kode simbolik; dan

d. kode tindakan merupakan kode yang berupa tindakan atau aksi dalam suatu cerita. Dalam naskah Мор-тор terdapat empat kode tindakan.

2) Makna-makna dalam naskah Mopmop, di antaranya:

a. dialog Meureuhui merupakan cerita tentang konflik batin yang 
dirasakan oleh seorang istri karena adanya pengaruh orang ketiga;

b. salam pembuka merupakan ucapan salam yang diucapkan penutur kepada lawan tutur saat pementasan; dan

c. pantun pohon nipah merupakan pantun teka-teki yang mempunyai makna tersembunyi yang disampaikan oleh penutur kepada lawan tutur dengan harapan agar lawan tutur dapat menerima lamaran penutur.

Berdasarkan simpulan di atas, saran dalam penelitian ini adalah sebagai berikut.

1) Menyarankan mahasiswa yang hendak mengkaji tentang semiotik, untuk dapat mengkaji lebih dalam mengenai kode semiotik.

2) Disarankan kepada Dosen pengampu mata kuliah analisis wacana, untuk mengarahkan kepada mahasiswa secara mendalam materi mengenai semiotik.

3) Penelitian ini hanya mengkaji kode semiotik dan makna. Disarankan bagi peneliti lainnya untuk menyempurnakan penelitiannya yang berhubungan dengan kajian semiotik.

\section{DAFTAR PUSTAKA}

Adri. 2009. "Sistem Kode Cerpen Indonesia Populer dalam Kumpulan Cerpen Damarcinna Karya Bustan Basir Maras: Pendekatan Semiotika Roland Barthes." Ujung Pandang. Jurnal Sawerigading, Vol. 15 Nomor 2. Halaman 245-260.

Albar, Muhammad Wasith. 2018. "Analisis Semiotik Charles Sander Pierce Tentang Taktik Kehidupan Manusia: Dua Karya Kontemporer Putu Sutawijaya." Lensa Budaya, Vol. 13 Nomor 2. Hal 123-136.
Agustina, Belia. 2017. "Analisis Semiotika Unsur-unsur Kebudayaan Palembang dalam Film Ada Surga di Rumahmu." Skripsi. Palembang: Universitas Islam Negeri Raden Fatah.

Agustina, Susianti. 2016. "Analisis Semiotik Roland Barthes Novel Hujan Karya Tere Liye dan Rencana Pelaksanaan Pembelajaranya di Kelas XI SMA." Skripsi. Purworejo: Universitas Muhammadiyah Purworejo.

Agustina, Lili. 2017. "Analisis Semiotik dalam Kumpulan Cerpen Air Mata Ibuku dalam Semangkuk Sup Ayam." Banjarmasin. Jurnal Bahasa, Sastra, dan Pengajarannya, Vol. 2 Nomor 1. Halaman 54-63.

Aiman, Umul. 2017. "Pelestarian Kesenian Mop-mop di Kabupaten Aceh Utara." Semarang. Jurnal Imaji, Vol. 15 Nomor 1. Halaman 113-120.

Ambarani dan Nazia Maharani Umaya. 2012. Semiotika: Teori dan Aplikasi pada Karya Sastra. Semarang: IKIP PGRI Semarang Press.

Arikunto, Suharsimi. 2016. Prosedur Penelitian: Suatu Pendekatan Praktik. Jakarta: Rineka Cipta.

Astika, I Made. 2014. "Cerpen "Kisah Pilot Bejo" Karya Budi Darma (Analisis Semiotika Roland Barthes)." Bali. Jurnal Prasi, Vol. 9 Nomor 18. Hal 15-28.

Darojah, Inarozatuzzakiyati. 2013. "Nilai-nilai Moral dalam Novel 5 
cm (Kajian Semiotik Roland Barthes)." Tesis. Semarang: IAIN Walisongo.

Hafiar, Hanny, Jimi Narotama, dan Detta Rahmawan. 2017. "Analisis Semiotika pada Cover Novel Trilogi Karya Vira Safitri." Universitas Padjadjaran. Jurnal Nomosleca, Vol. 3 Nomor 1. Halaman 506-514.

Kurniawan, Rendi. 2017. "Telaah Makna Kurzgeschichte Laternen Karya Marie Luise Kaschnitz Melalui Analisis Lima Kode Semiotik Roland Barthes.” Skripsi. Yogyakarta: Universitas Negeri Yogyakarta.

Mahsun. 2012. Metode Penelitian Bahasa. Jakarta: PT Raja Grafindo Persada.

Maisyaroh. 2016. "Analisis Semiotik dalam Naskah Drama Die Physiker Karya Friedrich Durrenmatt." Universitas Negeri Surabaya. Jurnal Identitaet, Vol. V Nomor 2. Halaman 1-4.

Mirnawati, Amrah Kasim, Abd. Rauf Aliah. 2016. "Simbol Mitologi dalam Karya Sastra Teks AlBarzani (Analisis Semiotika Roland Barthes)." Makassar. Jurnal Diskursus Islam, Vol. 4 Nomor 3. Halaman 468-483.

Nasution, Ikhwanuddin. 2008. "Sistem dan Kode Semiotika dalam Sastra: Suatu Proses Komunikasi.” Jurnal
Ilmiah Bahasa dan Sastra, Vol. IV Nomor 2. Halaman 109-115.

Putri, Arsa Sinta Herjuna. 2015. "Pesan Moral dalam Roman Heinrich Von Ofterdingen Karya Novalis Melalui Analisis Lima Kode Semiotik Roland Barthes." Skripsi. Yogyakarta: Universitas Negeri Yogyakarta.

Rasyidin. 2018. "Kesenian Mop-mop di Kabupaten Aceh Utara: Struktur Pertunjukan Kesenian Mop-mop." Bireun. Majalah Ilmiah Universitas Almuslim, Vol. 10 Nomor 2. Halaman 37-43.

Sahid, Nur. 2016. Semiotika. Yogyakarta: Gigih Pustaka Mandiri.

Sobur, Alex. 2002. Analisis Teks Media: Suatu Pengantar untuk Analisis Wacana, Analisis Semiotik, dan Analisis Framing. Bandung: PT Remaja Rosdakarya.

Yuliantini, Yanti Dwi, dan Adita Widara Putra. 2017. "Semiotika dalam Novel Rembulan Tenggelam di Wajahmu Karya Tere Liye." Universitas Galuh. Jurnal Literasi, Vol. 1 Nomor 2. Halaman 65-72.

Yuliastuti, Hani. 2011. "Makna Dakwah Cerpen "Ketika Cinta Mengabadikan Cinta" dalam Kumpulan Cerpen di Atas Sajadah Cinta Karya Habiburrahman El Shirazy (Analisis Semiotik Roland Barthes)." Skripsi. Jakarta: Universitas Indonesia. 